\title{
Gamification and Education: Achievements, Cognitive Loads, and Views of Students
}

\author{
http://dx.doi.org/10.3991/ijet.v11i07.5455 \\ Zeynep Turan, Zeynep Avinc, Kadir Kara, Yuksel Goktas \\ Ataturk University, Erzurum/TURKEY
}

\begin{abstract}
In this mixed method research study, the effect of gamification strategies on students' cognitive load levels and achievements was examined along with student opinions about gamification. The topic of spreadsheets was covered for six weeks in a sixth grade information technologies and software course. The sample consisted of a control group of 48 students who were trained via traditional procedures and an experimental group of 46 students who were trained using gamification strategies. Independent sample t-test, Mann-Whitney $U$ test and descriptive analysis were applied to the data. A significant difference was found between the two groups that indicated higher achievement in the experimental group. When comparing cognitive load levels, the experimental group also scored higher than the control group. Interviews indicated that the students had positive views about gamification strategies.
\end{abstract}

Index Terms-Gamification, Cognitive Load, Games, Game Based Learning, Gamifying

\section{INTRODUCTION}

Gamification is a new trend where game elements are used in unlikely contexts, such as education, health or social areas, and marketing (Hakulinen, Auvinen \& Korhonen, 2015; Hanus \& Fox, 2015; Koivisto \& Hamari, 2014). Gamification is becoming more popular day by day, and it is used especially widely in the business world. Any application, task, process, or context may be gamified. One of its most popular current applications is the social networking website Foursquare, where users share their locations and win rewards. For instance, the title of mayor is given to users with the greatest number of checkins at a given location (Glover, 2013). The base of gamification is formed by game elements such as reward and competition, as demonstrated by Foursquare. Accordingly, Gartner, an information technology research company known world-wide, has stated that $50 \%$ of companies will be using gamification strategies in 2015 (Gartner, 2011). These developments have attracted the attention of the education world, raising the question, "Is gamification useful in education?" The New Media Consortium's recent Horizon Report (2014 Higher Education Edition) indicated that gamification is becoming widespread among educators, as it increases the creativity and productivity of students. Using games in education has been common for generations, but gamification is quite a new concept. Badges, rewards, and cumulative, competitive scores provide visible incentives for student behaviors, but gamification offers much more than these simple ideas. The most valuable reasons to encourage gamification in education are its stimulating elements, such as immediate feedback, feeling of achievement, challenge and defeating (Kapp, 2012).
Based on the literature, gamification may be used to provide incentives for expected behaviors in education and to ensure that these behaviors help students to reach intended learning outcomes (Lee \& Hammer, 2011; Simões, Redondo, \& Vilas, 2013). Moreover, gamification has many cognitive, emotional, and social benefits (Domínguez et al., 2013; Lee \& Hammer, 2011). Individuals have the chance to improve problem solving skills as they spend countless hours applying them in games (Gee, 2003). Individuals also become ready to face learning failures, since games can evoke feelings of curiosity and disappointment (Lazzaro, 2004). The literature has further demonstrated that the use of gamification in education increases motivation towards and participation in a course (Hakulinen, Auvinen \& Korhonen, 2015; Lee \& Hammer, 2011; Muntean, 2011). In a study that investigated the effect of gamification on learning for university students, an online learning application was developed using game strategies; gamification was shown to increase motivation and participation but had no effect in terms of achievement (Domínguez et al., 2013). Hanus and Fox (2015) investigated gamification's effects on students' motivation, social comparison, effort, satisfaction, empowerment, and academic performance over 16 weeks. They found that gamified course students had lower motivation, satisfaction, empowerment, and achievement scores than traditional course students.

In another study, social networking websites and learning management systems used in gamification strategies were compared; while the gamification method increased student participation, students trained by traditional methods were more successful (Marcos, Domínguez, Saenz-deNavarrete, \& Pagés, 2014). The researchers attributed the success of traditional approaches to the competitive nature of the gamification applications and the students' overall familiarity with traditional ways. Emotional responses such as anxiety can emerge as a result of the competition to reach resources and rewards in games (Hwang, Hong, Cheng, Peng, \& Wu, 2013). This situation may affect stress levels and result in distraction from the main aim (Jones, 1995). Anxiety is closely related to performance and consumes cognitive resources. In this respect, the cognitive load levels of students may be negatively affected by gamification. Moreover, Kirschner, Sweller, and Clark (2006) suggested that constructivist learning environments can exceed students' working memory capacity. Cognitive load theory suggests that overloading working memory with high cognitive loads negatively affects students (Sweller, Van Merrienboer, \& Paas, 1998). Accordingly, instructional designs should be developed that help learners to use their memory capacities effectively (Paas \& Van Merrienboer, 1993; Sweller et al., 1998). 
Sweller, van Merrienboer, and Paas (1998) introduced three different cognitive loads: intrinsic, extraneous, and germane. Intrinsic load, depending on the content that must be learned, is formed in the active working memory. Due to the nature of man, this intrinsic load will be higher for difficult issues or complex information (Clark, Nguyen, \& Sweller, 2006). The extraneous load is the overloaded working memory, which accumulates as a result of poorly designed instructional materials, causing adverse affects to learning (Clark et al., 2006). The germane load refers to the formation of mental structures and processes that enable regulation (Sweller et al., 1998). Excessive knowledge, applications, and life experiences that do not provide benefit to learning cause redundant cognitive load in the learning environment, which also adversely affects learning (Paas \& Van Merrienboer, 1993). Therefore, decreasing factors that boost cognitive loads in the learning environment is suggested (Jeung, Chandler, \& Sweller, 1997). During a course period where gamification is used, learners should consider all aspects of the activity, including rewards and learning objectives. The students do group work with their friends and compete at the same time, trying to win rewards and points while completing tasks in gamification settings. Competition can affect learning both positively and negatively (Reeve \& Deci, 1996). Investigating the effect of this situation on memory capacity and cognitive load during learning may offer important insight into gamification strategies for education.

Various studies do appear in the literature, but the number is insufficient, especially with regard to experimental studies about gamification (Domínguez et al., 2013; Hanus \& Fox, 2015). According to Landers and Callan (2011), studies in this area are still in their infancy. In addition, Simões, Redondo and Vilas (2013) stated in their study that gamification increases motivation but indicated that more studies should be conducted on different platforms. Few studies have been done in this field, with almost none addressing the effect of gamification on cognitive load. This study will make a major contribution to the literature and provides a valuable sample and resource for teachers and schools that want to implement the gamification method.

Three questions were investigated for the current study:

- Does gamification have an effect on the achievement of students in education?

- Does gamification have an effect on the cognitive load levels of students in education?

- What are the views of students on using gamification in education?

\section{METHODS}

This study applied the mixed research method: collecting, analyzing, and interpreting both qualitative and quantitative data about the main facts in a single study or a series of studies (McMillan \& Schumacher, 2010). Gamification in education was evaluated, and the effect of this method on the achievements and cognitive load levels of students were examined. Quasi-experimental design was used to investigate the effect of gamification on cognitive load and achievement, which comprised the quantitative dimension of the study. Quasi-experimental studies differentiate from experimental research in terms of random assignment of the groups (Cresswell, 2014). Since the groups were not assigned randomly, the study design was quasi-experimental. For the qualitative dimension, data was collected from the experiment group by using semistructured interviews to evaluate gamification.

\section{A. Sampling and Implementation Process}

The sample of the study was composed of 94 sixth grade students from two schools in Turkey. A unit on spreadsheets was taught to the 46 students in the experimental group using gamification strategies and to the 48 students in the control group using traditional methods. The implementation stage of the study took place over six weeks for two course hours (120 minutes) each week.

The same content was taught in both groups during the same weeks with the same activities. Gamification strategies were added to the activities of the experimental group. Elements of gamification such as competition, rewards, collecting points, and group work were implemented. In most applications, rewards and badges were displayed on the leader board. In this study, the badges were collected in an electronic environment, ClassDojo. A username was registered for each student, and an online class was formed (see Figure 1).

After completing activities, the students received rewards from this platform (see Figure 2).

In addition, using the online game-based question/answer platform Kahoot, the students reviewed the week's topic after each lesson (see Figure 3).

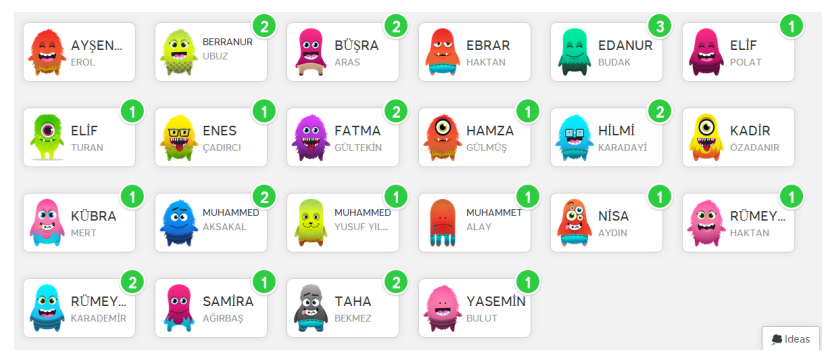

Figure 1. ClassDojo, Leader board in online class
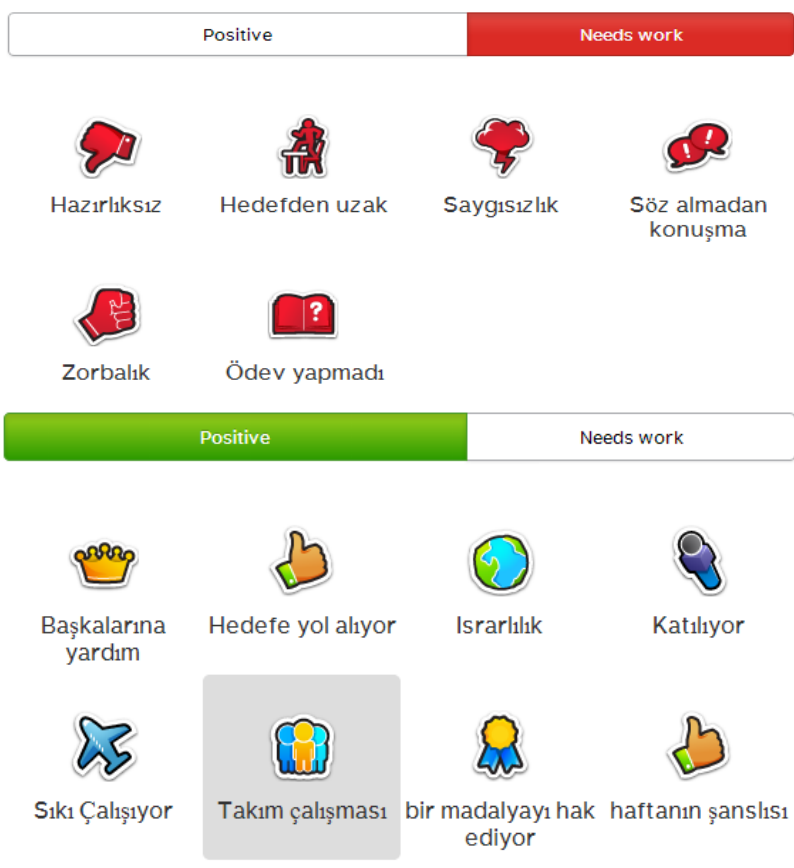

Figure 2. ClassDojo, Badges and rewards given to students 

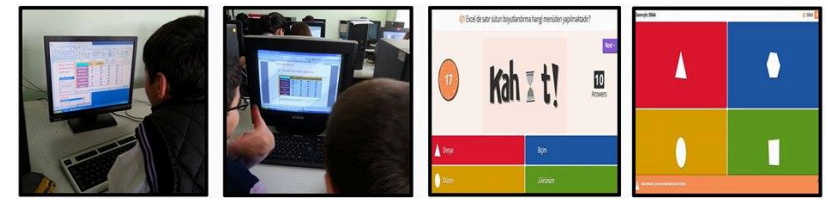

Figure 3. Example images from the implementation of Kahoot

The students in the control group completed the same activities using traditional methods. The teacher taught the topic, and the students did the given activities. Kahoot and ClassDojo were used in every lesson for the experimental group. As seen in Table 1, every week had a different gamification activity.

\section{B. Data Collection Tools}

In the study, a cognitive load scale, achievement test, and semi-structured interview form were used as data collection tools. The achievement test was developed by the researchers and included 10 multiple choice questions about the spreadsheets unit. It was used to evaluate the effects of gamification on achievement. The test was reviewed by two information technologies teachers, and revisions were made according to their feedback before determining the final version. Each question was worth 10 points, with a maximum score of 100 . Cronbach's alpha was tested and found to be 0.72 .

The cognitive load scale was developed by Paas and Van Merrienboer (1993) and translated to Turkish by Kılıç and Karadeniz (2004), and it was used to evaluate the effect of gamification on cognitive load (Appendix A). The cognitive load scale is a subjective rating of one question from 1 to 9 . The validity and reliability of this scale was tested by Kılıç and Karadeniz (2004). Cronbach's alpha was found to be 0.78 . The Spearman Brown test result was found to be 0.79 . The students responded to the cognitive load scale at the end of each week, six times in total. The average of these six measurements represented the cognitive load score for each student.

The semi-structured interview form (Appendix B) was developed by the researchers and used to determine the views of students on using gamification in education. Two experts were consulted to ensure the reliability and validity of the interview form, and the final form was revised per their feedback.

\section{Data Analysis}

The quantitative data in this study was analyzed by SPSS software. Before data analysis, some tests regarding homogeneity and normality were applied to ensure the internal consistency of the research. Although the achievement variable data set did not have normal distribution, the cognitive load variable data set did. In order to analyze the distribution of data, the Kolmogorov Smirnov test was conducted, and the achievement variable test result was found to be $p=.000$. The cognitive load variable test result was found to be $p=.200$. Therefore, parametric and non-parametric tests were used to analyze the data, such as the independent sample t-test and MannWhitney $U$ test, applying inferential statistics to determine whether a difference occurred between achievement and cognitive load levels of students. The significance level in inferential analysis was considered to be 0.05 . Additionally, descriptive analysis was applied to the qualitative data.
TABLE I.

WEEKLY COURSE CONTENT AND ACTIVITIES

\begin{tabular}{|c|c|c|}
\hline Week & $\begin{array}{l}\text { Control } \\
\text { Group }\end{array}$ & Experimental Group \\
\hline $\begin{array}{l}\text { Week } 1 \text { - Intro- } \\
\text { duction to Excel } \\
\text { - Line and } \\
\text { column sizing }\end{array}$ & $\begin{array}{c}\text { Creating a } \\
\text { checker board }\end{array}$ & $\begin{array}{l}\text { Creating a checker board (cups } \\
\text { for the first three, cups given for } \\
\text { the behaviors of students during } \\
\text { lesson) } \\
\text { Kahoot }\end{array}$ \\
\hline $\begin{array}{l}\text { Week } 2 \text { - Cells } \\
\text { - Fill color }\end{array}$ & Letter activity & $\begin{array}{l}\text { - Letter activity (cups for the first } \\
\text { three, cups given for the behav- } \\
\text { iors of students during lesson) } \\
\text { Kahoot }\end{array}$ \\
\hline $\begin{array}{c}\text { Week } 3-\text { Calcu- } \\
\text { lations }\end{array}$ & Flow sheet & $\begin{array}{l}\text { Flow sheet (cups for the first } \\
\text { three, cups given for the behav- } \\
\text { iors of students during lesson) } \\
\text { Kahoot }\end{array}$ \\
\hline $\begin{array}{c}\text { Week } 4-\text { Calcu- } \\
\text { lations }\end{array}$ & $\begin{array}{l}\text { Addition, } \\
\text { mean formu- } \\
\text { la, taking } \\
\text { percentages }\end{array}$ & $\begin{array}{l}\text { - Addition, mean formula, taking } \\
\text { percentages (cups for the first } \\
\text { three, cups given for the behav- } \\
\text { iors of students during lesson) } \\
\text { Kahoot }\end{array}$ \\
\hline $\begin{array}{l}\text { Week } 5 \text { - Con- } \\
\text { ditional figura- } \\
\text { tion }\end{array}$ & $\begin{array}{l}\text { Conditional } \\
\text { figuration } \\
\text { activity }\end{array}$ & $\begin{array}{l}\text { - Conditional figuration activity } \\
\text { (understanding and learning the } \\
\text { activity after finding lecture } \\
\text { notes hidden in the computer) } \\
\text { Kahoot }\end{array}$ \\
\hline $\begin{array}{l}\text { Week } 6-\text { Men- } \\
\text { us and submen- } \\
\text { us }\end{array}$ & $\begin{array}{l}\text { Teaching } \\
\text { menus and } \\
\text { submenus }\end{array}$ & $\begin{array}{l}\text { Matching the menus and sub- } \\
\text { menus game (group work, cup } \\
\text { given to the first group) } \\
\text { Kahoot }\end{array}$ \\
\hline
\end{tabular}

TABLE II.

Mann-Whitney U Test Results Of Post-Test Scores

\begin{tabular}{|c|c|c|c|c|c|c|}
\hline \multirow{2}{*}{} & \multicolumn{2}{|c|}{$\begin{array}{c}\text { Experimental } \\
\text { Group (46) }\end{array}$} & \multicolumn{2}{|c|}{$\begin{array}{c}\text { Control Group } \\
\text { (48) }\end{array}$} & \multicolumn{2}{|c|}{} \\
\cline { 2 - 7 } & $\begin{array}{c}\text { Mean } \\
\text { Rank }\end{array}$ & $\begin{array}{c}\text { Sum of } \\
\text { Ranks }\end{array}$ & $\begin{array}{c}\text { Mean } \\
\text { Rank }\end{array}$ & $\begin{array}{c}\text { Sum of } \\
\text { Ranks }\end{array}$ & $\boldsymbol{U}$ & $\boldsymbol{p}$ \\
\hline $\begin{array}{c}\text { Post-test } \\
\text { score }\end{array}$ & 58.92 & 2710.50 & 36.55 & 1754.50 & 578.50 & .000 \\
\hline
\end{tabular}

\section{F1ND1NGS}

\section{A. Gamification and Student Achievement}

Since the academic achievement variable did not have normal distribution, a condition of parametric tests, the Mann-Whitney $U$ test, a non-parametric test, was used. When the pre-tests applied to the control and experimental groups were analyzed, no significant difference was seen: $\mathrm{U}=993, \mathrm{p}=.389$.

A significant difference was observed between the experimental and the control groups in terms of the academic achievement variable when the scores of the post-tests were analyzed: $U=578.5, z=-4,067, p=.000$. As seen in Table II, the academic achievement rate of the experimental group $(\mathrm{Md}=58.92)$ was higher than that of the control group $(\mathrm{Md}=36.55)$.

\section{B. Gamification and Cognitive Load}

The data obtained by considering the research question, "Does gamification have an effect on the cognitive load levels of students in education?", was analyzed using an independent sample t-test. As shown in Table III, a significant difference was found between cognitive load levels: $\mathrm{t}(92)=2.89, \mathrm{p}=.005$. The mean cognitive load score of 
the experimental group $(\bar{X}=3.98)$ was higher than that of the control group $(\bar{X}=3.25)$.

\section{Students Views on Gamification}

Qualitative data was collected from the 28 students in the experimental group via semi-structured interviews. The aim of these interviews was to obtain common views on the gamification method. Findings indicate that most of the students had positive responses. Most students liked the method $(\mathrm{n}=25)$ and wanted to use it in other courses $(\mathrm{n}=24)$. In addition, the students reported that this method made lessons fun $(n=17)$ and learning easier $(n=16)$. One student explained, "As the lesson became more enjoyable, I wanted to learn more and compete. At first we did not want to complete the tasks and activities given during the lessons. In this way we always want to have some activities" (Student 10). Another student expressed, "I think I learn better with the gamification method. I think this method is good for learning" (Student 19).

Even though most of the students had positive ideas about the gamification method, some students had negative opinions. A few students $(n=3)$ did not like the gamification method because it caused an unnecessarily competitive environment that resulted in uneasiness. Some students $(\mathrm{n}=2)$ found the method unnecessary, felt it had no benefit to learning $(n=3)$, and did not want to use it in other courses $(n=3)$. One student stated, "If I am to summarize this method with a single word, I would say redundant. It caused jealousy between students" (Student 1).

\section{CONCLUSION AND Discussion}

In this mixed method study, a gamification-based strategy was compared with traditional methods. The purpose of the study was to investigate the effect of gamification on students' achievements, cognitive load levels, and perceptions. The experimental group students, who were taught using the gamification method, earned better achievement scores than the control group students. Similarly, Simões et al. (2013) observed in their study held with students aged 6 to 12 that gamification made school more interesting and motivating, which accordingly increased achievement. Cheong, Cheong, and Filippou (2013) investigated the effect of gamification on learning, engagement and enjoyment, also found that gamification increased student learning level in their study. In contrast, Domínguez et al. (2013) found that gamification had no effect on student achievement in their study with university students. Hanus and Fox (2015) found that university students taught with gamification strategies had lower achievement scores than peers taught by traditional methods. This difference in terms of achievement might be caused by the design and content of the gamification process, as well as by the high average age in the study samples. In this direction, Koivisto and Hamari (2014) identified a negative correlation between age and ease of using gamification applications in their study on demographic differences in terms of perceived benefits of gamification.

Even though a higher success rate was obtained with the experimental group, the average cognitive load scores of the experimental group were quite higher than those of the control group. One possible reason for this difference stems from dealing with the necessities of gamification at the same time as completing tasks. This situation may be
TABLE III.

INDEPENDENT SAMPLE T-TEST RESULTS ACCORDING TO COGNITIVE LOAD SCORES

\begin{tabular}{|c|c|c|c|c|c|c|}
\hline & N & X & Sd & df & t & p \\
\cline { 1 - 5 } Experimental Group & 46 & 3.98 & 1.34 & \multirow{2}{*}{92} & \multirow{2}{*}{2.89} & \multirow{2}{*}{.005} \\
\hline Control Group & 48 & 3.25 & 1.12 & & & \\
\hline
\end{tabular}

TABLE IV

Positive Thoughts Of Students

\begin{tabular}{|l|c|}
\hline \multicolumn{1}{|c|}{ Answer } & Frequency \\
\hline I like this method & 25 \\
\hline I want this method to be used in other courses & 24 \\
\hline This method has made the course more enjoyable & 17 \\
\hline I think I learn better with this method & 16 \\
\hline I liked cups and rewards the most in this method & 15 \\
\hline This method increased my attention to the course & 11 \\
\hline I liked being in a competition the most in this method & 9 \\
\hline $\begin{array}{l}\text { This method increased my communication with my } \\
\text { teacher }\end{array}$ & 2 \\
\hline
\end{tabular}

related to the redundancy effect from a cognitive load perspective. Sweller et al. (1998) reported that unnecessary elements in instructional designs increase extraneous cognitive load levels. This result may led to decreasing of germane load. Another reason for the high cognitive load level in the experimental group may be related to the goalfree effect of cognitive load theory. Sweller et al. (1998) suggested that goal-free tasks can decrease the extraneous cognitive load. Because gamification often has goals that must be achieved, students use their limited memory capacity to focus on those goals, taxing their cognitive load levels. Additional reasons for the high cognitive load may be the competition with other students, trying to win badges and rewards while completing activities. There is a known high positive correlation between competition anxiety and cognitive load (Hwang et al., 2013). Eysenck, Derakshan, Santos, and Calvo (2007) have suggested that high anxiety levels are closely related to work performance and depleted cognitive resources. Parallel with the results of this study, Marcos et al. (2014) found that gamification led to better performance in terms of success compared to social networking sites, but active participation was lower in the group that used gamification strategies. They determined the cause of low participation to be the competition. High levels of cognitive load, a clear result of this study, are thought to be caused by the competitive element of gamification. Gamification elements occupy the working memory capacities of students and inhibit focus; as a result, they demand more mental effort. Smith and Ayres (2014) have offered that even external factors, such as pain, can lead to high cognitive load levels. A lesson should be carefully designed to prevent overloading cognitive load and to highlight its contributions to cognitive and social dimensions.

According to the qualitative data obtained in the study, students showed positive attitudes towards gamification strategies and wanted other lessons to be taught via this method. Cheong et al. (2013) also found that students liked this method, which increased engagement. The competitive class environment and the chance to win rewards and cups affected the attention students paid to lessons and learning in a positive way. In the same way, in a study on fifth grade students, cups and rewards had a positive 
impact on cognitive understanding and success, and it was at least partially proven that external rewards such as cups and badges do not lead to negative results (Filsecker \& Hickey, 2014). Despite its accompanying high cognitive load, the interest in gamification may be related to the novelty effect for the experimental group (Koivisto \& Hamari, 2014).

In conclusion, gamification can increase both cognitive load and achievement levels, and students generally have positive thoughts regarding gamification strategies. When gamification is applied, the cognitive load factor must be considered and certain precautions must be taken to maximize effectiveness.

\section{A. Limitations and Future Directions}

The sample groups in the study were chosen from two schools per terms of time and attainability. The pre-test scores showed no meaningful difference between the groups. However, the selection of groups from two schools may be a restriction of the study because of the probability of socioeconomic differences. Another limitation for this study is that different teachers taught the experimental and control groups.

Suggestions for future studies

- The effect of gamification on success and cognitive load could be further investigated using a longer time interval and larger sample with stronger integration.

- The effect of gamification on different kinds of courses could be assessed.

- The effect of gamification on retention of learning could be researched. tion

Suggestions for managing cognitive load in gamifica-

- Activities could be designed with no goals; thus, students use their limited working memory capacity for learning the subject.

- Competition elements in class activities should be calculated for effectiveness in terms of anxiety.

- Complex gamification activities should not take place in the classroom.

\section{REFERENCES}

[1] Cheong, C., Cheong, F., \& Filippou, J. (2013, June). Quick quiz: A gamified approach for enhancing learning. Paper presented at the 17th Pacific Asia Conference on Information Systems, Jeju Island, Korea.

[2] Clark, R., Nguyen, F., \& Sweller, J. (2006). Efficiency in learning: Evidence-based guidelines to manage cognitive load. San Francisco: Pfeiffer.

[3] Creswell, J. W. (2014). Research design: Qualitative, quantitative, and mixed methods approaches (4th ed.). Thousand Oaks, CA: Sage.

[4] Domínguez, A., Saenz-de-Navarrete, J., De-Marcos, L., Fernández-Sanz, L., Pagés, C., \& Martínez-Herráiz, J. J. (2013). Gamifying learning experiences: Practical implications and outcomes. Computers \& Education, 63, 380-392. http://dx.doi.org/10.1016/ j.compedu.2012.12.020

[5] Eysenck, M. W., Derakshan, N., Santos, R., \& Calvo, M. G. (2007). Anxiety and cognitive performance: Attentional control theory. Emotion, 7, 336-353. http://dx.doi.org/10.1037/15283542.7.2.336

[6] Filsecker, M., \& Hickey, D. T. (2014). A multilevel analysis of the effects of external rewards on elementary students' motivation, engagement and learning in an educational game. Computers \& Ed- ucation, $\quad 75, \quad$ 136-148. http://dx.doi.org/10.1016/j.compedu. $\underline{2014.02 .008}$

[7] Gartner. (2011). Gartner SAYS BY 2015, MORE THAN 50 PERCENT OF ORGANIZATIONS THAT MANAGE INNOVATION PROCESSES WILL GAMIFY THOSE PROCESSES.Retrieved FROM HTTP://WWW.GARTNER.COM/NEWSROOM/ID/1629214.

[8] Gee, J. P. (2003). What video games have to teach us about learning and literacy. Computers in Entertainment, 1(1), 20. http://dx.doi.org/10.1145/950566.950595

[9] Glover, I. (2013). Play as you learn: Gamification as a technique for motivating learners. Retrieved from http://shura.shu.ac.uk/7172/1/Glover_-_Play_As_You_Learn_proceeding_112246.pdf

[10] Hakulinen, L., Auvinen, T., \& Korhonen, A. (2015). The effect of achievement badges on students'behavior: An empirical study in a university-level computer science course. International Journal of Emerging Technologies in Learning, 10(1), 18-28. http://dx.doi.org/10.3991/ijet.v10i1.4221

[11] Hanus, M. D., \& Fox, J. (2015). Assessing the effects of gamification in the classroom: A longitudinal study on intrinsic motivation, social comparison, satisfaction, effort, and academic performance. Computers \& Education, 80, 152-161. http://dx.doi.org/10.1016/ j.compedu.2014.08.019

[12] Hwang, M., Hong, J., Cheng, H., Peng, Y., \& Wu, N. (2013). Gender differences in cognitive load and competition anxiety affect 6th grade students' attitude toward playing and intention to play at a sequential or synchronous game. Computers \& Education, 60, 254-263. http://dx.doi.org/10.1016/j.compedu.2012. 06.014

[13] Jeung, H., Chandler, P., \& Sweller, J. (1997). The role of visual indicators in dual sensory mode instruction. Educational Psychology, 17(3), 329-343. http://dx.doi.org/10.1080/014434197 $\underline{0170307}$

[14] Jones, G. (1995). More than just a game: Research developments and issues in competitive anxiety in sport. British Journal of Psychology, $\quad 86, \quad 449-478 . \quad$ http://dx.doi.org/10.1111/j.20448295.1995.tb02565.x

[15] Kapp, K. M. (2012). The gamification of learning and instruction: Game-based methods and strategies for training and education. San Francisco, CA: Pfeiffer.

[16] Kılıç, E., \& Karadeniz, S. (2004). Specifying students' cognitive load and disorientation level in hypermedia. Educational Administration Theory and Practice, 40(1), 562-579.

[17] Kirschner, P. A., Sweller, J., \& Clark, R. E. (2006). Why minimal guidance during instruction does not work: An analysis of the failure of constructivist, discovery, problem-based, experiential, and inquiry-based teaching. Educational Psychologist, 41, 75-86. http://dx.doi.org/10.1207/s15326985ep4102_1

[18] Koivisto, J., \& Hamari, J. (2014). Demographic differences in perceived benefits from gamification. Computers in Human Behavior, 35, 179-188. http://dx.doi.org/10.1016/j.chb.2014.03.007

[19] Landers, R. N., \& Callan, R. C. (2011). Casual social games as serious games: The psychology of gamification in undergraduate education and employee training. In M. Ma, A. Oikonomou, \& L. C. Jain (Eds.), Serious Games and Edutainment Applications (pp. 399-424). Surrey, UK: Springer. http://dx.doi.org/10.1007/978-14471-2161-9 20

[20] Lazzaro, N. (2004). Why we play games: Four keys to more emotion without story. Retrieved from https://files.nyu.edu/fm9/public/ Downloads/11/xeodesign_whyweplaygames.pdf

[21] Lee, J., \& Hammer, J. (2011). Gamification in education: What, how, why bother? Academic Exchange Quarterly, 15(2), 1-5.

[22] Marcos, L., Domínguez, A., Saenz-de-Navarrete, J., \& Pagés, C. (2014). An empirical study comparing gamification and social networking on e-learning. Computers \& Education, 75, 82-91. http://dx.doi.org/10.1016/j.compedu.2014.01.012

[23] McMillan, J. H., \& Schumacher, S. (2010). Research in education: Evidence-based inquiry (7th ed.). Boston, MA: Pearson.

[24] Muntean, C. I. (2011, October). Raising engagement in e-learning through gamification. Proceedings of the 6th International Conference on Virtual Learning, 323-329. Retrieved from http://www.icvl.eu/2011/disc/icvl/documente/pdf/met/ICVL Mod elsAndMethodologies_paper42.pdf 
[25] Paas, F., Renkl, A., \& Sweller, J. (2003). Cognitive load theory: A special issue of Educational Psychologist. Educational Psychologist, $38(1)$.

[26] Paas, F., \& Van Merrienboer, J. J. G. (1993). The efficiency of instructional conditions: An approach to combine mental-effort and performance measures. Human Factors, 35, 737-743.

[27] Reeve, J., \& Deci, E. L. (1996). Elements of the competitive situation that affect intrinsic motivation. Personality \& Social Psychology Bulletin, 22, 24-33. http://dx.doi.org/10.1177/014 6167296221003

[28] Simões, J., Redondo, R. D., \& Vilas, A. F. (2013). A social gamification framework for a K-6 learning platform. Computers in Human Behavior, 29(2), 345-353. http://dx.doi.org/10.1016/j.chb. 2012.06.007

[29] Smith, A., \& Ayres, P. (2014). The impact of persistent pain on working memory and learning. Educational Psychology Review, 26, 245-264. http://dx.doi.org/10.1007/s10648-013-9247-x

[30] Sweller, J., Van Merrienboer, J. J. G., \& Paas, F. G. (1998). Cognitive architecture and instructional design. Educational Psychology Review, 10(3), 251-296. http://dx.doi.org/10.1023/A:1022 193728205

\section{AUTHORS}

Zeynep Turan, PhD., is Assistant Professor at the Department of Computer Education \& Instructional Technology, Ataturk University, 25240 - Erzurum, Turkey, (zeynepatauniv@hotmail.com).

Zeynep Avinc is a Master of Science student at the Department of Computer Education \& Instructional Technology, Ataturk University, 25240 - Erzurum, Turkey (zeynep.avinc@gmail.com).

Kadir Kara is a Master of Science student at the Department of Computer Education \& Instructional Technology, Ataturk University, 25240 - Erzurum, Turkey (kadirkara2013@gmail.com).

Yuksel Goktas, PhD., is Associate Professor at the Department of Computer Education \& Instructional Technology, Ataturk University, 25240 - Erzurum, Turkey (yuksel.goktas@hotmail.com).

Submitted 12 January 2016. Published as resubmitted by the authors 30 March 2016.

Appendix A. Cognitive LoAd ScAle

How easy or difficult did you find the task?

\begin{tabular}{|c|c|c|c|c|c|c|c|}
\hline $\begin{array}{c}\text { Extremely } \\
\text { easy }\end{array}$ & Very easy & Easy & Rather easy & $\begin{array}{c}\text { Neither easy } \\
\text { nor difficult }\end{array}$ & $\begin{array}{c}\text { Rather } \\
\text { difficult }\end{array}$ & Difficult & Very difficult \\
\hline 1 & 2 & 3 & 4 & 5 & 6 & 7 & 8 \\
difficult
\end{tabular}

\section{APPENDIX B. INTERVIEW QUESTIONS}

1. What were your thoughts when you first heard about the gamification?

2. What did you like most about the gamification?

3. What do you consider to be the benefits of gamification?

4. How did the gamification impact your learning?

5. Did you experience any problems with the gamification?

6. Do you want to learn other lessons with gamification strategies?

7. If you had to sum up your gamification experience in one word, what would it be? 